\title{
Control Activities and Financial Accountability in South Nyanza County Governments in Kenya
}

\author{
Manyange Nyasimi Michael * \\ College of Economics and Management, Department of Accounting and Finance Kampala International \\ University \\ P.O BOX 20, 000, Kampala, Uganda \\ Aluonzi Burani \\ College of Economics and Management, Departmet of Accounting and Finance Kampala International \\ University \\ P.O BOX 20, 000, Kampala, Uganda \\ Omweno Nyameiyio Enock \\ College of Economics and Management, Department of Accounting and Finance Kampala International \\ University \\ P.O BOX 20, 000, Kampala, Uganda \\ Mabonga Eric \\ College of Economics and Management, Department of Accounting and Finance Kampala International \\ University \\ P.O BOX 20, 000, Kampala, Uganda
}

\begin{abstract}
This study was about control activities and financial accountability in South Nyanza County Governments, Kenya. County governments in Kenya has been beset by a number of challenges; lack of both budget estimates and implementation document; there is no documentation against which accountability can be gauged. The objectives of the study were to examine the relationship between control activities and value for money, transparency and financial reporting. The study adopted descriptive cross sectional and correlational designs with both quantitative and qualitative approaches. From a total population of 2066 a sample size of 335 respondents was obtained using Slovene's formula. Data were collected using self administered questionnaires and in depth interviews. Quantitative data was analyzed using Means and standard deviations, Pearson linear correlation coefficient and regression analysis. Qualitative data analysis was done using narrative and thematic analysis. The results indicate that there is a positive and significant relationship between control activities and value for money $(\mathrm{r}=0.446$, $\mathrm{p}=0.00)$, transparency $(\mathrm{r}=0.479, \mathrm{p}=0.00$. $)$ and financial reporting $(\mathrm{r}=0.547, \mathrm{p}=0.00)$. The contribution of value for money, transparency and financial reporting was $34.7 \%\left(\mathrm{R}^{2}=0.347\right)$. The model was significant $(\mathrm{F}=147.934$, $\mathrm{p}=0.00)$. The study concluded that there is relationship between control activities and value for money, transparency and financial reporting. The study recommends that the management of the counties should consider control activities, value for money, transparency and financial reporting very important in order to achieve the objectives of financial accountability.
\end{abstract}

Keywords: Control Activities, Value for Money, Transparency and Financial Reporting

DOI: $10.7176 /$ RJFA/11-6-04

Publication date:March $31^{\text {st }} 2020$

\section{Introduction}

Financial accountability is the assessment of value for money and acceptance by individuals of personal responsibility for their actions in relation to quality of their outputs and decisions (Brown, 1998). Furthermore, Magu (2016) asserted that financial accountability is the balance budgets to comply with accounting and lawful requirements, preparing precise and up-to-date financial statements, and putting into practice systems of internal controls to shrink risk of theft or fraud. This means that financial accountability entails bringing to stand the full power of the institutions most precious and important resources, its people, maintaining and improving the value of the institution's programs and services. Financial accountability is at all times associated to good governance in public organizations to manage public funds, conduct public matter and warranty the realization of human rights in a way basically free from misuse and corruption of public resources, as well as obeying the rule of law (Bhuiyan \& Amagoh, 2011)

Financial accountability plays a big role in public sectors since it enhances the provision of effectiveness and transparency in service delivery and value for money. The improvement and increasing of awareness of new public management reforms for more than two decades is ongoing in government of Kenya. This is evidenced by the 
financial reforms and reorganization to enhance public service delivery (Tarofder et al., 2017; Thomas \& Nadiyasu, 2017). The arguments for high quality control in governance started in the late 1980s owing to the beginning of New Public Management in the United Kingdom and other parts of the world which later led to the acceptance of new approach to public sector management reform (Grace, 2015). It is important that the government present correct and absolute information about expenditure and accounting information to strengthen accountability and their own integrity (IFAC, 2012).

The issue of financial accountability is myth in most African Countries. For instance, corruption in public sector is rampant and hardly a day goes by without it being mentioned in the press (Atuilik \& Salia, 2019). Other financial scandals in the Continent include pension scam worth N40 billion (about US\$308 million) in Nigerial Ishola,Abikoye and Olajide ( 2015), Ebola case in Sierra Leone state worth 84 billion Leones (about 12 million pounds) which was meant to fight Ebola virus (O'Carroll, 2015).In Kenya the situation is not different. For example Kenya is experiencing persistent financial scandals as reported by Auditors general's report 2013/2014 which revealed that only $3.8 \%$ of total revenue collected was reasonably recorded. Kenya is ranked 139 out of 168 by Transparency International in its 2015 corruption perception index which reveals serious issues of financial accountability in public sector. It is against this background, this study about the relationship between control activities and financial accountability in South Nyanza County Government was conducted. Control Activities (CA) being the independent variable was operationalised as Separation of duties(SD), Verification of Assets (VOA) and Reconciliation of statements(RS) and Financial accountability (FA) being the dependent variable was conceptualized as Financial Reporting(FR),Value for money (VFM) and Transparency (TR)

\subsection{Statement of the Problem}

Financial accountability is used to gauge ways in which Revenue and expenditure are effectively and efficiently utilized to add value to service delivery (Evelyne \& Boateng, 2016). However, County governments in Kenya has been beset by a number of challenges; lack of both budget estimates and implementation documents hence citizens cannot hold county governments of South Nyanza financially accountable. Other challenges include lack of financial documentation against which accountability can be gauged (Auditor General Report, 2014). According to Auditor General's report for the financial year ended $30^{\text {th }}$ June 2014 the financial accountability in South Nyanza county governments has been low and include payments for uncompleted work. The Report further indicates that the menace is widespread. For example there is misuse of public funds including lack of accountability for millions of public funds by members of county government. From practical world the provisions of these services have been marred by poor financial accountability in South Nyanza County Governments (Auditors General Report, 2016/2017). This suffices the conduct of this study especially in South Nyanza County Governments in Kenya. The study therefore, intends to examine how control activities can help County Governments to improve financial accountability in Kenya.

\subsection{Purpose of the Study}

The purpose of the study was to examine the relationship between control activities and financial accountability in South Nyanza county Government in Kenya

\subsection{Objectives of the study}

The study was guided by the following objective:-

1.3.1 To examine the relationship between Control activities and Value for money in South Nyanza County Government in Kenya

1.3.2 To determine the relationship between Control Activities and transparency in South Nyanza County Government.

1.3.3 To establish the relationship between Control Activities and financial reporting in South Nyanza County Government in Kenya.

\section{LITERATURE REVIEW}

\subsubsection{Control Activities and Financial Accountability}

According to Shelton and Whittington (2008) control activities are the rules and measures implemented by the company to ensure that management's orders are performed out for efficiency and proper accountability. The activities are grouped into operations, financial reporting and compliance. The study further indicated that these control activities involves activities such as approvals, authorizations, verifications, reconciliation, segregation of duties and authority and security of assets. Internal control is at the heart of accountability for effective use of resources and national building Abdirisaq and Yassin (2014), they also indicated that internal controls aid as the first line of protection in preservation of resources and preventing errors and scam. This was in line with Muraleetharan (2013) who indicated that external controls such as external audit are concerned with enhancing the reliability of financial performance thereby increasing financial accountability among different stakeholders. 
In the study conducted by Ahmad et al., (2017) on the effect of internal control activity on financial accountability and transparency in local government area of Borno state, by means of cross sectional study plan, the study drew a sample of 330 respondents out of 1886 staffs. Data were collected through questionnaire and consequently, it was analyzed using descriptive statistics, chi squire and regression analysis. Using chi -squire it was found out that there is lack of efficiency of internal control activity in the local governments in that area and regression analysis revealed that internal control activity has significant effect on financial accountability. The study recommends that ministry dealings in union with the local governments' management should revise the laws and procedures of internal control mechanisms in order to construct the efficiency in financial responsibility and clearness of the local administration. Kisanyanya and omagwa (2018) indicated that institutions of higher learning had sufficient and valuable control activities because there was satisfactory separation of duties in the departments of accounts and finance, accepted internal audit reports and physical control to avoid surplus allocation of money. It was found out that control activities have a positive significant effect on the financial performance of the institution. Aramide and Bashir (2015) put forward that the commencement of internal control structure has been looked at as an essential component of business organizations worldwide. It is applied for the intention of shielding organization's resources to avoid scam and ineffectiveness and also helps to evaluate the level of performance in governments across the globe, (Kamau, 2014; Aramide and Bashir, 2015) opined that to decrease the threat of mistakes, misuse or unlawful act, control activities ought to be put in place to make sure that approval procedures are well documented and clearly communicated to employees.

Aramide and Bashir (2015) opined that the procedure of financial accountability can only be successful through appropriate internal control activity which is thought to be a useful device for financial accountability and transparency at local government. Litvack (2016) accepted that the higher the level of accountability, the more transparent the local government is alleged to be. Transparency depends on accountability and the latter on the usefulness of internal control activity in action. This study therefore examines the effect of internal control system on financial accountability in South Nyanza County Governments in Kenya. Omolehinwa (2003) stated that public institutions are provided to deliver services to the people and are not usually for profit, they are based on fund accounting on cash basis with the budget to be implemented by money collected through taxes for provision of social benefits and sustainability, hence control activities will ensure strong accountability in the county governments.Sanusi \& Mustapha (2015) asserted that most control activities are ignored by most financial institutions due to lack of knowledge and experience to those who are concerned this has resulted to under estimation of internal control hence causing financial accountability to decline because of fraud and misappropriation of funds. County governments tend to ignore internal control activities like segregation of duties, cross checking among many others and put much reliance on technological advancement which may lead to a lot of misstatement in financial reports.

According to Amudo and Inanga (2009) for internal control system to operate effectively some specific procedures needs to be necessitated in a government environment. This also comes as a result of recent corporate scandals that have helped managers to put stringent measures for clear internal control to enhance financial accountability. The scandals emphasize the need to scrutinize, evaluate and formulate systems of check and balances to guide executives in decision making. Muraleetharan (2013) noted that internal control is a changing process the organization must undertake in order to produce honest, reliable, accurate and informative financial reports periodically. Internal control system and financial accountability are related and it can be observed that internal control systems gives stronger assurance on financial accountability and there is need for it to be used by executives in policy formulation and decision making.

\subsubsection{Transparency}

The issue of transparency in financial accountability is highlighted by researcher like Taylor and Francis (2015) who argues that financial accountability include transparency and open government initiatives have become vehicles to increase authenticity and trust in government, progress citizen commitment and limit fraud and maladministration.Government's financial accountability and trasparency have become the crucial factor on the performance of political systems and are projected to enforce accountability of the County government to the relevant stakeholders.

\subsubsection{Financial Reporting}

Jenning et al.,(2008) contended that increasing reliability on financial reporting in government institutions is very important for the citizens who use the information for decision making process. The idea of financial accountability in internal control activities has been cited by David (2001) who opined that financial accountability targets can be achieved through effective internal control activities which can protect the loss and resources and provide timely and reliable financial reporting which can free an organization from its reputation and other consequences and ensure laws and regulations are followed to the lather. The same sentiments can be applied in county government setup to help in realistic reassurance regarding the attainment of an entity with regard to reliability of financial reporting and accountability. 


\subsubsection{Value for money.}

Evelyn and Boateng (2016) opined that value for money is a choice based on the whole life cost of the project or service. Given the limited resources available to government, ensuring value for money in financial accountability is key to ensure the best use of accessible funds. A well- functioning public instituion system is critical for improved delivery of decentralised goods, works and services

\section{Research Methodology}

The study employed descriptive correlational and cross-sectional survey design with the population of 2066 respondents. Using Slovenes sampling technique; a sample size of 335 was obtained. Data were collected using self administered questionnaires, measured using a five Likert scale ranging from `1-5, 1 being Strongly Disagree, 2 being Disagree, 3 being Not Sure, 4 being Agree and 5 being strongly Agree. The interpretation of the data analyzed were as follows

Table 1: Interpretation of the Mean Scores.

\begin{tabular}{lll}
\hline Mean range & Response range & Interpretation \\
$4.21-5.00$ & strongly agree & Very satisfactory \\
$3.41-4.20$ & Agree & Satisfactory \\
$2.61-3.40$ & not sure & fairly satisfactory \\
$1.81-2.60$ & Disagree & Unsatisfactory \\
$1.00-1.80$ & Strongly disagree & Very unsatisfactory \\
\hline
\end{tabular}

\section{Source: Primary Data (2019)}

The study also adopted the in depth interview method and documentary review method to collect qualitative data. Construct validity test was conducted where six items loaded with eigene value above 1 . The reliability test was conducted which yielded result of $\alpha=.799$. Data were analysed at uni-variate, bi-variate and multi-variate analysis.

\section{Results and interpretation}

\subsection{The results of Univariate analysis}

The descriptive statistics used to analyse data at univariate level included measures of central tendency especially the arithmetic means and standard deviations. The arithmetic means are useful in describing in average terms the views of the respondents (Amin, 2005). The standard deviation is useful to explain the spread of the data (Amin,2005).The results obtained for the constructs of financial accountability and Control activities are presented in table 2 .

Table 2: Descriptive Results.

\begin{tabular}{|l|l|l|l|}
\hline Variables & Means & SD & INTEPRETATION \\
\hline VFM & 3.28 & 0.834 & Fairly Satisfactory \\
\hline TR & 3.70 & 0.727 & Satisfactory \\
\hline FR & 3.72 & 0.798 & Satisfactory \\
\hline CA & 3.81 & 0.660 & Satisfactory \\
\hline
\end{tabular}

The results in Table 2 reveal that as regards value for money construct of financial accountability, $\bar{x}=3.28$ and $\mathrm{SD}=0.834$ which was interpreted as fairly satisfactory. The results suggest that the respondents are not all that satisfied whether the financial position of the county government is well ascertained, respect the budgets in implementation of financial decisions, levies are dully collected, high level of financial compliance, high level of appropriation of funds and increase in value for money.

In terms of transparency the mean $\overline{\mathrm{x}}=3.70$ and $\mathrm{SD}=0.727$ which was interpreted as satisfactory. The results suggested that the respondents were all satisfied with respect to whether the reports are examined by the auditors, employees are accountable for their roles, periodical meetings are held to discuss progress of activities, receipts for all transactions are available, sufficient monitoring of financial activities and robust expenditure and corrective action taken to address weaknesses in these county governments.

Concerning financial reporting $\overline{\mathrm{x}}=3.72$ and $\mathrm{SD}=0.798$ which was interpreted as satisfactory. The results suggested that the respondents were all satisfied with respect to accounting practices conforming to accepted standards, employees communicating appropriately to their supervisors, Information and processing capabilities having improved, employees submitting weekly reports, the current information flow being quick and effective and the Counties having a reporting mechanism to its Stakeholders

In relation to control activities $\overline{\mathrm{x}}=3.81$ and $\mathrm{SD}=0.660$ which was interpreted as satisfactory. The results suggested that Controls employed include authorization, approvals, physical count and reconciliation, Availability of policies and procedures to facilitate the recording and accounting transactions in compliance with laws \& regulations, Submission of annual work plans and budget by the country, well built accounting and financial system. The county has policies and procedures for addressing segregation of duties, identification of suitable 
technology controls and the risk of third parties.

\subsection{Bi viriate results}

The researcher further tested whether the control activities is positively and significantly correlated with each construct of financial accountability in South Nyanza county government in Kenya, using Persona's linear correlation coefficient (PLCC). The results are presented in table 3.

Table 3: Pearson Correlations for Control Activities and Financial Accountability constructs

\begin{tabular}{|l|l|l|l|l|}
\hline Variables correlated & r-value & Sig. & Interpretation & Decision on Ho \\
\hline CA $^{\#}$ Vs Value for Money & $.446^{* *}$ & .000 & Significant correlation & Rejected \\
\hline CA Vs Transparency & $.479^{* *}$ & .000 & Significant correlation & Rejected \\
\hline CA Vs Financial Reporting & $.547^{* *}$ & .000 & Significant correlation & Rejected \\
\hline CA Vs Overall Financial Accountability & $.532^{* *}$ & .000 & Significant correlation & Rejected \\
\hline
\end{tabular}

**. Correlation is significant at the 0.01 level (2-tailed). \# = Control Activities

4.2.1 Relationship between control activities and value for money in South Nyanza County government in Kenya.

The first objective of this study was to test the relationship between control activities and value for money in South Nyanza County government in Kenya. The results in table 3 indicate that there is a significant relationship between control activities and value for money $(\mathbf{r}=\mathbf{0 . 4 4 6}, \mathbf{p}=\mathbf{0 . 0 0 0})$. This suggests that when there is improvement in control activities, there will be increased value for money and vice versa.

4.2.2 Relationship between control activities and transparency in South Nyanza County government in Kenya.

The second objective of this study was to test the relationship between control activities and transparency in South Nyanza County government in Kenya. The results in table 3 indicate that there is a significant relationship between control activities and transparency $(\mathbf{r}=\mathbf{0 . 4 7 9}, \mathbf{p}=\mathbf{0 . 0 0 0})$ this suggests that improvement in control activities increases transparency and vice versa.

4.2.3 Relationship between control activities and financial reporting in South Nyanza County government in Kenya.

The third objective of this study was to test the relationship between control activities and financial reporting in South Nyanza County government in Kenya. The results in table 3 indicate that there is a significant relationship between control activities and financial reporting $(r=0.4460 .000)$. This suggests that when there is improvement in control activities, there will be improvement in financial reporting and vice versa

\subsection{Results of Multivariate Analysis.}

As also pointed out by Kline (2011), the researcher wanted to establish the extent to which financial accountability is predicted by the control activities. The regression results are presented in table 4

Table 4: Regression Analysis for Control Activities and Financial Accountability

\begin{tabular}{|l|l|l|l|}
\hline Variables Regressed & \multicolumn{1}{|l|}{$\mathbf{R}^{\mathbf{2}}$} & F-value & Sig. \\
\hline Control Activities Vs. Financial Accountability & .347 & 147.934 & .000 \\
\hline Standardized Coefficients & Beta & T & \\
\hline (Constant) & 1.288 & 6.797 & .000 \\
\hline Control Activities & .589 & 12.163 & .000 \\
\hline
\end{tabular}

The results in Table 4 indicate that, the control activities explained $34.7 \%$ towards variations in financial accountability of the county governments $\left(\mathrm{R}^{2}=0.347\right)$. This means that a unit change in control activities reflects $35 \%$ changes in financial accountability. The magnitudes of the beta suggested that control activities significantly influenced financial accountability $(\beta=0.589, \mathrm{t}=12.163$ and $\mathrm{p}=0.000)$. The model is significant since $\mathrm{F}=147.934$ and $p=0.000<0.001$.

\section{DISCUSSIONS}

From the analysis, the views of the respondent indicate that they are fairly satisfied with the accounting practices when it comes to value for money in South Nyanza County government in Kenya. This suggests that the county government should improve ascertaining financial position, respect the budget implementation decisions, dully collect levies, highly comply with financial standards and increase the value for money. This is further supported by the bivariate results that indicated a positive and significant relationship between control activities and value for money. This means that control activities play a big role in influencing value for money. It is therefore, important for County government to take into consideration the importance of control activities as part of internal control systems. The findings were supported by the views of the respondents .For instance, the first respondent 
had this to say.

"The introduction of IFMIS to control the flow of funds and also periodical auditing at the end of the year (internal and external audit) help finances to be controlled in an appropriate manner."

The findings of this study are in congruence with earlier studies such as Ndifon and Patrick (2014) whose findings established that there was a relationship between control activities and financial accountability in Tertiary institutions in Nigeria. Similarly, Kisanyanya and omagwa (2018) indicated that institutions of higher learning had sufficient and valuable control activities because there was satisfactory separation of duties in the departments of accounts and finance, accepted internal audit reports and physical control to avoid surplus allocation of money. Other authors whose finding are in agreement with this study include Aramide and Bashir (2015), Kamau (2014) and Aristanti (2015).

In terms of transparency, the results suggested that respondents were satisfied. This suggests that county governments should consider the issue of examination of reports by auditors very important in addition to employees being held accountable for their acts. There is need by county government to conduct periodic meetings, discuss progress; record transactions in addition to sufficient monitoring of financial activities. This will help the county government to take corrective actions if omissions are made by the finance personnel. The study further realized that there is a positive and significant relationship between transparency and financial accountability this means that when there is transparency in financial transactions accountability will be easier and will achieve its objectives. The same views were expressed by one of the respondents as

The County government has always provided important information which is available on the internet for the citizens to access hence it creates awareness and transparency for its people to understand the government procedures in accomplishing tasks.

The findings of this study are supported by the extant literature. For instance The issue of transparency in financial accountability is highlighted by researcher like Taylor and Francis (2015) who argues that financial accountability include transparency and open government initiatives have become vehicles to increase authenticity and trust in government, progress citizen commitment and limit fraud and maladministration.Government's financial accountability and trasparency have become the crucial factor on the performance of political systems and are projected to enforce accountability of the County government to the relevant stakeholders.

Concerning financial reporting, the views of the respondents indicated that they were satisfied with the activities of the financial reporting this means that the county government should take factors such as employees communicating appropriately to their supervisors, the use of the ICT in accounting process weekly submission of reports to stakehlolders and others. The findings of the study further indicate that there is a positive and significant relationship between financial reporting and financial accountability. This suggests financial reporting is a key factor in auditing process because it is the process through with the stakeholders are informed of the financial position of the county government. One interviewee had this to say.

"The integrated financial management system (IFMS) has been provided by the county governments to control use of expenditure, payment dispensation, reporting and budgeting for governments and other institutions."

The findings on this study are supported by earlier researchers such as Jenning et al.,(2008) contended that increasing reliability on financial reporting in government institutions is very important for the citizens who use the information for decision making process and David (2001) who opined that financial accountability targets can be achieved through effective internal control activities.

\section{Conclusions}

The study concludes that control activities have significant and positive relationship with value for money, transparency and financial reporting. It is therefore, important for county Governors to consider issues relating to control activities value for money, transparency and financial reporting very important in the management of finances of the county government

\section{Recommendation}

From the findings and conclusions of this study, the researcher derived the following recommendation; The study recommends that the management of the counties should boost the level of control activities to enhance positive effect on financial accountability by putting in place procedures and policies to guarantee that directives are properly followed in the county governments

\section{References}

1. Abdirisaq, I.M., \& Yassin, A.(2014).Assessing the financial accountability of the Somali Federal Government Organizations. Journal of Public Policy and Administration Research, 2014; 4 (2): 61-66

2. Ishola, S.A. Abikoye O.A., \& Olajide R.A (2015).Effects of Internal Control System in Nigeria Public Sector. 
International Journal of Economics, Commerce and Management, 3(6), 1093-1104.

3. Ahamad et.al.(2017). Effect of internal control activity on financial accountability and transparency in local government area of Borno state, Nigeria. European Journal of Business and Management, 9 (30):58-65.

4. Amudo, A, \& Inanga, E.L.,(2009).Evaluation of Internal Control Systems: A case study from Uganda. International Research Journal of Finance and Economics, 19 (27),125-126.

5. Amin E.M. (2005). Social Science Research. Conception, Methodology and Analysis, Kampala, Uganda: Makerere University Printery.

6. Aramide S.F., \& Bashir M.M., (2015). The Effectiveness of Internal Control System and Financial Accountability at Local Government Level In Nigeria. International Journal of Research in Business Management, 3 (8), 1-6.

7. Atuilik, W.A \& Salia, H., (2019).Impact of IPSAS adoption on Transparency and Accountability in managing Public fund in developing countries. Evidence from Liberia. Journal of Accounting and Taxation, 11(6), 99110.

8. Auditor General Report (2014). Auditor-General Report on the public Accounts of Kenya for the year 2014.

9. Auditor General Report (2017). Report of the Auditor-General on the public Accounts of Kenya.

10. Bhuiyan, S.H \& Amagoh F., (2011).Public sector reform in Kazakhstan: Issues and perspectives. International Journal of Public Sector Management, 24 (3), 227-249.

11. Brown, G.(1998).Accountability and performance measurements. ACCA Student Newsletter: BPC catalogues East Kilbride Ltd. London.

12. David J (2001).Company Law in Uganda. Fountain Publishers. Kampala, Uganda.

13. Evelyn N.A, Boateng K.P.(2016). Measures of Ensuring value for Money in Public Procurement.Journal of Logistics Management, 5 ( 1), 22-31.

14. Grace, N.(2015). New public management and accrual accounting basis for transparency and new public Management and accrual accounting basis for transparency and accountability in the Nigerian public sector.

15. IFAC (2012). International Public Sector Accounting Standards (IPSASs) and Statistical Bases of Financial Reporting: An Analysis of Differences and Recommendations for Convergence. New York: International Federation of Accountants.

16. Kamau C. (2014). Effect of internal control on the financial performance of manufacturing firms Kenya, Unpublished thesis: University of Nairobi, Kenya;

17. Kisanyanya, A.G.\& Omagwa,J.,(2018).Internal control systems and financial performance of Public Institutions of Higher Learning in Vihiga County, Kenya.Journal of Business and Management, 20(4),23197668.

18. Kline, B (2011). Principles and Practice of Structural Equation Modeling, Third Edition (Methodology in the Social Sciences) 3rd Edition, 1-6.

19. Magu, J.K., (2016). Kibati P. Influence of Internal Control Systems on Financial Performance of Kenya Farmers' Association Limited. International Journal of Economics, Commerce and Management, 4(4), 783800.

20. Ndifon, E. \& Patrick, E., (2014). Impact of internal control activities on Financial performance of Tertiary Institutions in Nigeria. Journal of Economics and Sustainable Development. 5 ( 6).

21. Litvack J.(2016).Accountability, transparency and corruption in decentralized governance.

22. Muraleathran, P. (2013). Internal Control and Impact of Financial Performance of Organization. University of Jaffana.

23. Omolehinwa, E. (2003). Government Budgeting in Nigeria, Lagos, Pumark Nig Ltd, 1-14.

24. Sanusi \& Mustapha. (2015). The Effectiveness of Internal Control Systems and Financial Accountabiity at Local Government in Nigeria. International Journal of Research in Business Management, 3 ( 8): 1-6.

25. Shelton \& Whittington (2008). The influence of the auditors reports on investors' evaluations after the Serbanes-Oxley Act, Managerial Auditing Journal. 23 (2).

26. Taylor \& Francis .(2015).Measuring Local government transparency.Journal of management Review.

27. Tarofder A.K. Azam S.F \& Jalal,A.N.,(2017). Operational or strategic benefits: Empirical investigation of internet adoption in supply chain management. Management Research Review, 40(1), 28 - 52.

28. Thomas I.,\& Nadiyasu, J. B., (2017). Public Sector Financial Management Reform and International Accounting Standards ( IPSAS ), 8(12), 125-132. 